\title{
PENGARUH SUHU TERHADAP KARAKTERISTIK FISIKOKIMIA DAN OPTIK BROKOLI SELAMA PROSES PENGERINGAN VAKUM DENGAN TEKANAN $15 \mathrm{cmHg}$
}

\author{
Asri Widyasanti ${ }^{\left.1^{*}\right)}$, Sudaryanto ${ }^{1)}$, Rizky Arini ${ }^{1)}$, dan Ali Asgar ${ }^{2)}$ \\ ${ }^{1}$ Departemen Teknik Pertanian dan Biosistem, Fakultas Teknologi Industri Pertanian, \\ Universitas Padjadjaran, Jl. Bandung Sumedang km 21, Jatinangor, Sumedang, 40600 \\ ${ }^{2}$ Balai Penelitian Tanaman Sayur, Jl. Tangkuban Perahu 517 Lembang, Bandung Barat 40791 \\ Email: asriwidyasanti@gmail.com
}

\begin{abstract}
ABSTRAK
Brokoli merupakan salah satu jenis sayuran yang mengandung berbagai vitamin dan mineral. Akan tetapi, brokoli merupakan komoditas yang perishable, apabila disimpan tanpa penanganan pasca panen yang sesuai dan tepat. Pengeringan vakum merupakan salah satu penanganan pasca panen yang cocok untuk karakteristik dari brokoli. Penelitian ini bertujuan untuk mengetahui rendemen parsial dan total dari pengeringan vakum brokoli dan pengaruh proses pengeringan vakum terhadap karakteristik fisik dan kimia brokoli kering. Penelitian ini menggunakan metode analisis deskriptif dengan perlakuan suhu pengeringan $50^{\circ} \mathrm{C}$ dan $60^{\circ} \mathrm{C}$ dengan tekanan vakum sebesar $15 \mathrm{cmHg}$ yang dilakukan sebanyak 3 ulangan. Hasil penelitian menunjukkan bahwa perlakuan suhu pengeringan $60^{\circ} \mathrm{C}$ dengan tekanan vakum $15 \mathrm{cmHg}$ merupakan perlakuan terbaik dengan rasio pengerutan $16,67 \%$, rasio rehidrasi 518,27 $\%$, kadar air akhir 5,64 \%bk, bulk density $1056 \mathrm{~kg} / \mathrm{m}^{3}$, protein 30,97\%, vitamin C 189,24 mg/100 g, Total Color Difference (TCD) 23,8, rendemen parsial pengeringan 8,99\%, dan rendemen total 4,168 $\%$. Semakin tinggi suhu pengeringan maka nilai rendemen pengeringan, rendemen total, rasio pengerutan, kadar air akhir, nilai total perbedaan warna, bulk density, protein, dan vitamin C semakin rendah sedangkan nilai rasio rehidrasi semakin tinggi.

Kata kunci-brokoli; fisikokimia; karakteristik optik; pengeringan vakum; suhu pengeringan
\end{abstract}

\section{PENDAHULUAN}

Indonesia adalah negara agraris yang beriklim tropis dan matahari bersinar sepanjang tahun. Pertanian merupakan mata pencaharian utama sebagian besar masyarakat di Indonesia. Namun, masalah utama yang sering dihadapi adalah bahan hasil pertanian yang bersifat mudah rusak (perishable) salah satunya adalah komoditas sayuran brokoli.

Brokoli merupakan sayuran yang mengandung berbagai vitamin dan mineral, seperti $2,82 \mathrm{~g}$ protein dan 89,2 mg vitamin C. Akan tetapi, menurut Agustina (2010), daya simpan brokoli tanpa perlakuan pascapanen seperti pendinginan dan pengeringan, hanya mampu bertahan maksimal 2 hari. Hal ini disebabkan oleh proses metabolisme brokoli. Produk pertanian setelah dipanen masih melakukan proses metabolisme hingga produk tersebut mengalami kerusakan. Selain itu, proses metabolisme ini didukung oleh keberadaan kadar air bahan yang tinggi, yaitu sebesar $90 \%$ basis basah.

Salah satu cara untuk mengawetkan dan mencegah kerusakan pada sayuran khususnya brokoli adalah dengan cara mengeringkannya. Melalui proses pengeringan, kandungan air dalam brokoli diturunkan hingga mencapai 5,64-6,05 \% bk. Rendahnya kandungan air pada brokoli kering ini menyebabkan meningkatnya umur simpan brokoli hal ini disebabkan karena air merupakan media terjadinya kerusakan pada bahan pangan. Akan tetapi, proses pengeringan yang kurang tepat dapat menyebabkan perubahan warna dan rasa serta aroma pada produk kering serta denaturasi protein. Hal ini diperkuat oleh pernyataan Ophardt (2003), bahwa kebanyakan protein pangan terdenaturasi jika dipanaskan pada suhu lebih dari $65^{\circ} \mathrm{C}$. Hal ini didukung oleh pernyataan karnagi (2010), protein mengalami banyak kerusakan pada suhu $70^{\circ} \mathrm{C}$. Selain itu, kandungan vitamin $\mathrm{C}$ pada bahan juga dapat berkurang akibat perlakuan panas yang kurang tepat, yaitu di atas $70{ }^{\circ} \mathrm{C}$. Kurang lebih setengah dari kandungan vitamin C akan rusak akibat pemanasan (Azeliya, 2013). Menurut Astuti (2007), bahwa suhu $50{ }^{\circ} \mathrm{C}$ dengan tekanan $15 \mathrm{cmHg}$ tidak menyebabkan terjadinya perubahan kadar protein secara signifikan. Pada perlakuan yang sama juga terjadi pada kandungan vitamin $\mathrm{C}$ pada lobak kering.

Saravacos dan Maroulis (2011), menyatakan bahwa penggunaan suhu pengeringan vakum pada suhu (50 dan 60$)^{\circ} \mathrm{C}$ akan memperlambat proses penurunan intensitas warna sebagai akibat dari proses difusi yang perlahan. 
Berdasarkan penelitian Astuti (2007), menyatakan bahwa pengeringan pada suhu $50^{\circ} \mathrm{C}$ dan tekanan vakum 200 mbar $(15 \mathrm{cmHg})$ merupakan perlakuan terbaik dalam pengeringan vakum lobak, dengan nilai warna lobak kering lebih baik. Pada suhu $50^{\circ} \mathrm{C}$, perubahan warna yang terjadi tidak signifikan sehingga warnanya masih seragam. Pada pengeringan dengan suhu $50^{\circ} \mathrm{C}$, penguapan terjadi secara perlahan-lahan sehingga hampir tidak terjadi pengeriputan dan produk seragam.

Pada penelitian Karnagi (2001) terhadap pengeringan vakum tepung jamur putih diperoleh hasil terbaik, yaitu kadar protein tertinggi pada perlakuan suhu $6{ }^{\circ} \mathrm{C}$ dengan tekanan vakum $15 \mathrm{cmHg}$ selama 4 jam. Hal serupa juga ditunjukkan oleh penelitian Astuti (2008), menyatakan bahwa pengeringan bawang merah dengan suhu $60^{\circ} \mathrm{C}$ dan tekanan vakum $15 \mathrm{cmHg}$ merupakan perlakuan terbaik karena tidak terjadi penurunan intensitas warna pada bahan yang disebabkan oleh tidak adanya reaksi antara antosianin dengan oksigen. Dari hasil penelitian-penelitian yang telah dilakukan sebelumnya, menunjukkan bahwa pengeringan vakum sangat cocok untuk bahan hasil pertanian yang sensitif terhadap perlakuan suhu tinggi dan dapat mempertahankan kualitas bahan hasil pertanian jika dibandingkan dengan metode pengeringan lainnya. Oleh karena itu, dilakukan pengeringan vakum dengan menggunakan dua variabel, yaitu suhu pengeringan $(50 \text { dan } 60)^{\circ} \mathrm{C}$ dan tekanan vakum sebesar $15 \mathrm{cmHg}$. Penggunaan tekanan vakum $15 \mathrm{cmHg}$ ini dilatarbelakangi oleh penelitian Karnagi (2001) yang menyatakan bahwa pada tekanan vakum yang lebih tinggi dari $15 \mathrm{cmHg}$, yaitu $5 \mathrm{cmHg}$ dikhawatirkan penguapan yang terjadi terlalu cepat sehingga dengan waktu pengeringan yang sama pada sampel dengan suhu $50^{\circ} \mathrm{C}$, slurry jamur sudah menjadi hangus. Selain itu, pada perlakuan suhu yang sama dan tekanan vakum $20 \mathrm{cmHg}$ diperoleh kadar protein yang jauh lebih rendah dibanding dengan tekanan $15 \mathrm{cmHg}$. Hal ini diperkirakan karena pada tekanan $20 \mathrm{cmHg}$, masih terjadi aktivitas enzim di dalam jamur yang dapat mendegradasi protein dalam jamur. Menurut Baochi, dkk., (2009), bahwa kadar air maksimal kubis kering yang sesuai dengan Standar India adalah 6,38 \% bk. Oleh karena itu, pada penelitian ini diharapkan kadar air akhir brokoli berkisar $(5,64-6,05) \%$ bk.

\section{METODOLOGI PENELITIAN}

\section{A. Alat dan Bahan}

Alat yang digunakan pada penelitian ini adalah oven vakum, pompa vakum, dan timbangan analitik. Bahan utama yang digunakan dalam penelitian ini adalah brokoli segar varietas green king dengan umur panen 60-70 HST yang diperoleh dari petani di Lembang, Jawa Barat.

\section{B. Prosedur Percobaan}

Metode penelitian yang digunakan adalah analisis deskriptif. Analisis deskriptif merupakan metode pengambilan kesimpulan dengan cara mendeskriptifkan data dari hasil analisis data penelitian yang dilakukan. Penelitian ini menggambarkan dan menginterpretasikan perubahan yang terjadi pada bahan selama proses penelitian. Perlakuan yang diterapkan pada penelitian ini adalah pengeringan vakum brokoli dengan suhu pengeringan $50^{\circ} \mathrm{C}$ dan $60^{\circ} \mathrm{C}$ dengan tekanan vakum sebesar $15 \mathrm{cmHg}$ dan diulang sebanyak 3 kali. Parameter yang dianalisis meliputi: Karakteristik fisik (rasio pengerutan, rasio rehidrasi, kadar air akhir, dan bulk density brokoli kering), karakteristik kimia (protein dan vitamin C brokoli kering), karakteristik optik (warna brokoli kering), dan parameter pendukung (rendemen parsial dan total serta laju pengeringan brokoli dan sifat termodinamika udara ruang pengering vakum).

Dalam penelitian ini terdapat beberapa langkah yang dilakukan untuk memperoleh produk brokoli kering. Berikut ini merupakan prosedur persiapan brokoli sebelum pengeringan vakum dilakukan:

\section{a. Sortasi dan Trimming}

Pada tahapan ini dilakukan pemilihan brokoli yang masih segar dengan ketentuan brokoli segar dengan kualitas I. Trimming dilakukan untuk memisahkan bahan yang digunakan, yaitu bunga brokoli dengan panjang $\pm 25 \mathrm{~mm}$ untuk proses selanjutnya dan membuang batang brokoli yang tidak terpakai.

\section{b. Pengecilan Ukuran}

Dilakukan dengan cara pemotongan secara melintang dengan ketebalan $\pm 3 \mathrm{~mm}$. Hal ini dilakukan untuk mempercepat laju pengeringan. 


\section{c. Penimbangan}

Brokoli yang sudah disortasi, ditimbang sebanyak 750 gram bunga brokoli dengan menggunakan timbangan analitik.

\section{d. Pencucian}

Pencucian dilakukan sebagai proses pembersihan brokoli dari kotoran berupa tanah dan parasit (ulat) dengan menggunakan air bersih yang dialirkan dari kran.

\section{e. Blanching}

Proses ini dilakukan untuk mencegah terjadinya browning enzimatispada brokoli kering.

\section{f. Pendinginan}

Pendinginan dilakukan dengan cara merendam brokoli di dalam air dingin bersuhu $10^{\circ} \mathrm{C}$, proses ini dilakukan dengan tujuan untuk memberikan efek kejut sehingga proses pelunakan jaringan yang berlebihan, kematangan, kehilangan rasa, kerusakan nutrisi-nutrisi penting yang terdapat pada brokoli pasca blanching dapat dihentikan (Arthey dan Dennis, 1991).

\section{HASIL DAN PEMBAHASAN}

\section{A. Rasio Pengerutan Brokoli Kering}

Pengerutan adalah salah satu parameter yang sangat diperhitungkan dalam proses pengeringan karena merupakan salah satu indikator kualitas mutu produk kering. Tabel 1 menunjukkan nilai rasio pengerutan brokoli kering.

Tabel 1. Pengaruh Suhu Pengeringan Vakum terhadap Rasio Pengerutan (RP)

\begin{tabular}{ccc}
\hline \multirow{2}{*}{ Suhu $\left({ }^{\circ} \mathrm{C}\right)$} & Perlakuan & Rata-rata RP $(\%)$ \\
\cline { 2 - 2 } & Tekanan Vakum $(\mathrm{cmHg})$ & \\
\hline 50 & 15 & 33,33 \\
60 & 15 & 16,67 \\
\hline
\end{tabular}

Suhu pengeringan vakum mempengaruhi rasio pengerutan brokoli. Pada suhu pengeringan $60{ }^{\circ} \mathrm{C}$ dengan tekanan vakum $15 \mathrm{cmHg}$ menghasilkan rasio pengerutan sebesar $16,67 \%$, sedangkan pada suhu pengeringan $50{ }^{\circ} \mathrm{C}$ dengan tekanan vakum $15 \mathrm{cmHg}$ menghasilkan rasio pengerutan sebesar 33,33 \%. Mayor dan Sereno (2004), menyatakan bahwa pengerutan bahan akan memberikan dampak negatif pada kualitas bahan kering. Pengerutan juga menyebabkan kemampuan rehidrasi dari produk kering menurun.

\section{B. Rasio Rehidrasi Brokoli Kering}

Kualitas produk kering salah satunya dapat ditentukan dengan sifat rehidrasi. Sifat rehidrasi adalah kemampuan produk kering dalam menyerap air sehingga mendekati kondisi segarnya. Pada proses rehidrasi terjadi peningkatan massa brokoli hingga empat kali lipat dari kondisi keringnya. Peningkatan ini terjadi karena proses gelatinisasi selama proses rehidrasi. Dinding sel akan menyerap air dan melunak jika bahan kering direhidrasi. Adanya elastisitas pada dinding sel maka dinding sel akan kembali ke bentuk semula. Setiap perlakuan penanganan pascapanen termasuk pengeringan vakum akan mempengaruhi elastisitas dinding sel brokoli sehingga akan mempengaruhi nilai rehidrasi dari jaringan brokoli. Tabel 2 menunjukkan perbandingan nilai rasio rehidrasi brokoli kering.

Tabel 2. Pengaruh Suhu Pengeringan Vakum terhadap Rasio Rehidrasi (RR)

\begin{tabular}{ccc}
\hline \multirow{2}{*}{ Suhu $\left({ }^{\circ} \mathrm{C}\right)$} & Perlakuan & \\
\cline { 2 - 3 } & Tekanan Vakum $(\mathrm{cmHg})$ & Rata-rata RR (\%) \\
\hline 50 & 15 & 386,25 \\
60 & 15 & 518,27 \\
\hline
\end{tabular}

Nilai rasio rehidrasi diperoleh dari perbandingan massa brokoli setelah direhidrasi dengan massa brokoli kering. Terlihat pada Tabel 2, pengeringan vakum brokoli dengan suhu $50{ }^{\circ} \mathrm{C}$ dengan 
tekanan vakum $15 \mathrm{cmHg}$ menghasilkan nilai rasio rehidrasi sebesar 386,25\%, sedangkan pada suhu pengeringan $60{ }^{\circ} \mathrm{C}$ dengan tekanan vakum $15 \mathrm{cmHg}$ menghasilkan nilai rasio rehidrasi sebesar $518,27 \%$.

Asgar dan Musaddad (2006), nilai rehidrasi yang semakin tinggi menunjukkan kemampuan produk kering menyerap air semakin tinggi, serta tingkat elastisitas dinding sel semakin baik dan begitu pula sebaliknya. Nilai rehidrasi yang tinggi sangat diharapkan pada produk kering, karena menunjukkan bahwa produk kering tersebut mendekati bentuk semula atau memiliki mutu fisik yang baik.

\section{Kadar Air Akhir Brokoli Kering}

Penentuan nilai kadar air akhir bahan pada proses pengeringan sangat penting dilakukan. Hal ini bertujuan untuk menghambat proses metabolisme bahan sehingga dapat memperpanjang umur simpan dari bahan pangan yang dikeringkan. Hasil analisis nilai kadar air akhir brokoli kering disajikan pada Tabel 3.

Tabel 3. Rata-rata Kadar Air Akhir

\begin{tabular}{ccc}
\hline \multirow{2}{*}{ Suhu $\left({ }^{\circ} \mathrm{C}\right)$} & Perlakuan & Rata-rata Kadar Air \\
\cline { 2 - 3 } & Tekanan Vakum $(\mathrm{cmHg})$ & 6,05 \\
\hline 50 & 15 & 5,64 \\
60 & 15 & $5,64)$ \\
\hline
\end{tabular}

Nilai kadar air akhir pada perlakuan suhu pengeringan $50{ }^{\circ} \mathrm{C}$ dengan tekanan $15 \mathrm{cmHg}$ dan suhu pengeringan $60{ }^{\circ} \mathrm{C}$ dengan tekanan $15 \mathrm{cmHg}$ yang dihasilkan berbeda-beda, yaitu $6,05 \% \mathrm{bk}$ untuk pengeringan $50{ }^{\circ} \mathrm{C}$ dengan tekanan vakum $15 \mathrm{cmHg}$, sedangkan pada suhu pengeringan $60{ }^{\circ} \mathrm{C}$ dengan tekanan vakum $15 \mathrm{cmHg}$ menghasilkan brokoli kering dengan kadar air akhir sebesar 5,64 $\%$ bk.

\section{Bulk Density Brokoli Kering}

Bulk density merupakan salah satu karakteristik fisik yang sering digunakan untuk merencanakan pengemasan, volume alat pengolahan atau sarana transportasi. Nilai bulk density dari hasil pengamatan disajikan pada Tabel 4.

Tabel 4. Rata-rata Nilai Bulk Density (BD)

\begin{tabular}{ccc}
\hline Suhu $\left({ }^{\circ} \mathrm{C}\right)$ & Perlakuan & Rata-rata BD $\left(\mathrm{kg} / \mathrm{m}^{3}\right)$ \\
\cline { 2 - 2 } & Tekanan vakum $(\mathrm{cmHg})$ & 1155,99 \\
50 & 15 & 1056,00 \\
\hline
\end{tabular}

Brokoli kering hasil pengeringan vakum memiliki nilai bulk density berkisar antara $\left(1056,00-1155,99 \mathrm{~kg} / \mathrm{m}^{3}\right)$. Berdasarkan Tabel 4, semakin tinggi suhu pengeringan maka nilai bulk density akan semakin kecil. Hal ini sejalan dengan hasil penelitian Kusumawati,dkk., (2012) mengenai pengeringan tepung biji nangka, yaitu pada suhu pengeringan $80{ }^{\circ} \mathrm{C}$ memiliki nilai bulk density terkecil, sedangkan pada suhu pengeringan $60^{\circ} \mathrm{C}$ memiliki nilai bulk density terbesar.

\section{E. Kandungan Protein Brokoli Kering}

Kandungan gizi pada brokoli kering salah satunya adalah protein sangat penting untuk diketahui. Hal ini bertujuan untuk mengetahui apakah brokoli kering masih layak untuk dikonsumsi dengan nilai kandungan protein yang memenuhi kebutuhan tubuh. Pada penelitian ini, kadar protein diukur dengan menggunakan metode semi mikro kjeldahl. Hasil pengeringan vakum dengan perlakuan suhu $50{ }^{\circ} \mathrm{C}$ dan $60{ }^{\circ} \mathrm{C}$ dengan tekanan vakum $15 \mathrm{cmHg}$ menghasilkan brokoli kering dengan nilai protein yang berbeda- beda. Tabel 5 menunjukkan kadar protein pada brokoli kering. 
Tabel 5. Pengaruh Suhu Pengeringan Vakum terhadap Protein

\begin{tabular}{ccc}
\hline \multirow{2}{*}{ Suhu $\left({ }^{\circ} \mathrm{C}\right)$} & Perlakuan & Rata-rata Protein $(\%)$ \\
& Tekanan vakum $(\mathrm{cmHg})$ & \\
\hline 50 & 15 & 33,18 \\
60 & 15 & 30,97 \\
\hline
\end{tabular}

Berdasarkan Tabel 5, nilai protein yang diperoleh dari masing-masing perlakuan berbedabeda. Pada perlakuan suhu pengeringan $50^{\circ} \mathrm{C}$ dengan tekanan $15 \mathrm{cmHg}$ menghasilkan brokoli kering dengan protein sebesar $33,18 \%$, sedangkan pada perlakuan suhu pengeringan $60{ }^{\circ} \mathrm{C}$ dengan tekanan $15 \mathrm{cmHg}$ menghasilkan brokoli kering dengan protein sebesar 30,97\%.

Rendahnya nilai kandungan protein brokoli kering hasil pengeringan $60{ }^{\circ} \mathrm{C}$ dengan tekanan vakum $15 \mathrm{cmHg}$ disebabkan karena semakin tinggi suhu pengeringan, maka semakin banyak protein terdenaturasi (Purwitasari, dkk., 2014).

\section{F. Kandungan Vitamin C Brokoli Kering}

Kandungan gizi pada brokoli kering salah satunya adalah vitamin $\mathrm{C}$ sangat penting untuk diketahui. Hal ini bertujuan untuk mengetahui apakah brokoli kering masih layak untuk dikonsumsi dengan nilai kandungan vitamin $\mathrm{C}$ yang memenuhi kebutuhan tubuh. Pada penelitian ini, kadar vitamin $\mathrm{C}$ diukur dengan menggunakan metode iodometri. Tabel 6 menunjukkan kadar vitamin $\mathrm{C}$ pada brokoli kering.

Tabel 6. Pengaruh Suhu Pengeringan Vakum terhadap Vitamin C

\begin{tabular}{rcc}
\hline \multirow{2}{*}{ Suhu $\left({ }^{\circ} \mathrm{C}\right)$} & Perlakuan & Rata-rata Vitamin $\mathrm{C}(\mathrm{mg} / 100 \mathrm{~g})$ \\
\cline { 2 - 2 } 50 & 15 & 356,29 \\
60 & 15 & 189,24 \\
\hline
\end{tabular}

Berdasarkan Tabel 6, perlakuan suhu pengeringan $50{ }^{\circ} \mathrm{C}$ dengan tekanan $15 \mathrm{cmHg}$ menghasilkan brokoli kering dengan vitamin C sebesar $356,29 \mathrm{mg} / 100 \mathrm{~g}$, sedangkan pada perlakuan suhu pengeringan $60{ }^{\circ} \mathrm{C}$ dengan tekanan $15 \mathrm{cmHg}$ menghasilkan brokoli kering dengan vitamin $\mathrm{C}$ sebesar 189,24 mg/100g. Hal ini sejalan dengan penelitian Listiorini, dkk., (2014) mengenai kandungan vitamin $\mathrm{C}$ pulp srikaya, yaitu pada suhu pemanasan $50^{\circ} \mathrm{C}, 60^{\circ} \mathrm{C}$, dan $70{ }^{\circ} \mathrm{C}$ menghasilkan vitamin C masing- masing sebesar $31,8 \mathrm{mg} / 100 \mathrm{~g} ; 27,13 \mathrm{mg} / 100 \mathrm{~g}$; dan $26,84 \mathrm{mg} / 100 \mathrm{~g}$. Semakin tinggi suhu pengeringan maka kandungan vitamin $\mathrm{C}$ akan menyebabkan semakin banyak vitamin $\mathrm{C}$ yang teroksidasi menjadi senyawa diketogulonat.

\section{G. Karakteristik Optik}

Afrianti (2008), menyatakan bahwa warna merupakan salah satu atribut dari komponen kualitas bahan hasil pertanian yang dapat diterima oleh konsumen karena warna sebagai indikator terhadap kesegaran bahan. Begitu juga pada pengeringan, warna merupakan salah satu indikator mutu produk kering apabila dibandingkan dengan warna aslinya. Tabel 7 menunjukkan nilai Total Color Difference (TCD).

Tabel 7. Rata-rata Nilai TCD Brokoli Kering

\begin{tabular}{lcc}
\hline \multirow{2}{*}{ Suhu $\left({ }^{\circ} \mathrm{C}\right)$} & Perlakuan & TCD \\
\cline { 2 - 2 } & Tekanan vakum $(\mathrm{cmHg})$ & \\
\hline 50 & 15 & 28,86 \\
60 & 15 & 23,80 \\
\hline
\end{tabular}

Berdasarkan Tabel 7, pada perlakuan suhu pengeringan $50^{\circ} \mathrm{C}$ dengan tekanan vakum $15 \mathrm{cmHg}$ menghasilkan nilai TCD sebesar 28,86 sedangkan suhu pengeringan $60^{\circ} \mathrm{C}$ dengan tekanan vakum 15 cmHg menghasilkan nilai TCD sebesar 23,80. Perubahan warna brokoli kering yang terjadi termasuk ke dalam perubahan yang sangat banyak karena nilai TCD melebihi 12 (Widyasanti, 2010). 


\section{H. Rendemen Parsial}

Analisis nilai rendemen parsial dari suatu proses penanganan pascapanen brokoli perlu dilakukan untuk mengetahui kebutuhan bahan untuk mencapai bobot brokoli kering tertentu dan juga parameter efisiensi dari suatu proses. Jika nilai rendemen parsial diketahui maka perbaikan dari masingmasing proses dapat dilakukan dengan mudah untuk mencapai hasil yang optimal.

Nilai rendemen yang dipengaruhi oleh perlakuan suhu pengeringan adalah rendemen pengeringan. Rendemen pengeringan pada perlakuan suhu $50{ }^{\circ} \mathrm{C}$ dengan tekanan vakum $15 \mathrm{cmHg}$, yaitu $9,03 \%$ lebih tinggi dibandingkan dengan perlakuan suhu $60^{\circ} \mathrm{C}$ dengan tekanan vakum $15 \mathrm{cmHg}$, yaitu $8,99 \%$. Hal ini didukung oleh pendapat Wijana, dkk., (2013), bahwa penurunan rendemen disebabkan karena semakin tinggi suhu dan laju pengeringan maka kandungan air yang teruapkan akan lebih banyak sehingga mengakibatkan rendemen yang dihasikan menurun.

\section{Rendemen Total}

Pada proses penanganan pascapanen, nilai rendemen total sangat penting untuk diketahui. Hal ini bertujuan untuk mengetahui efektivitas dari suatu proses. Pada penelitian ini pengamatan rendemen total dilakukan dengan cara menimbang massa brokoli kering yang dihasilkan pada proses pengeringan vakum dan massa brokoli segar sebelum pengeringan vakum. Semakin besar massa brokoli kering yang dihasilkan maka semakin tinggi juga nilai rendemen total yang dihasilkan. Hasil pengamatan pada proses pengeringan vakum menunjukkan bahwa rendemen total yang dihasilkan pada setiap perlakuannya berbeda- beda. Gambar 1 menunjukkan rendemen total yang dihasilkan.

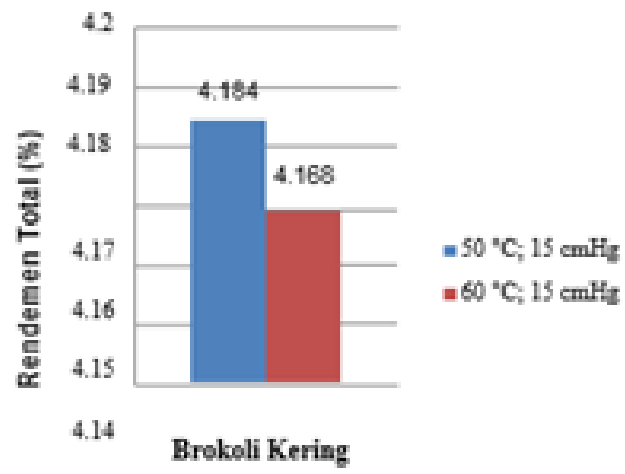

Gambar 1. Rendemen Total Brokoli Kering

Rendemen total yang dihasilkan pada suhu $60^{\circ} \mathrm{C}$ dengan tekanan vakum $15 \mathrm{cmHg}$, yaitu 4,168 lebih rendah dibandingkan dengan suhu $50^{\circ} \mathrm{C}$ dengan tekanan vakum $15 \mathrm{cmHg}$, yaitu $4,184 \%$. Perbedaan nilai rendemen total yang dihasilkan ini disebabkan oleh perbedaan laju pengeringan dari brokoli yang dikeringkan. Hal ini didukung oleh pendapat Wijana, dkk., (2013), menyatakan bahwa penurunan rendemen disebabkan karena semakin tinggi suhu dan laju pengeringan maka kandungan air yang teruapkan akan lebih banyak sehingga mengakibatkan rendemen yang dihasikan menurun.

\section{J. Laju Pengeringan Brokoli}

Kurva laju pengeringan dapat diperoleh dari perubahan nilai kadar air yang terjadi pada setiap selang waktu tertentu selama proses pengeringan vakum berlangsung. Kurva laju pengeringan dapat digunakan untuk mengetahui tingkat perubahan laju pengeringan yang terjadi selama proses pengeringan vakum. Pada penelitian ini menunjukkan hanya terdapat laju pengeringan menurun yang digambarkan pada Gambar 2.

Laju pengeringan menurun terjadi proses perpindahan massa air dari dalam bahan ke permukaan bahan kemudian perpindahan massa air dari permukaan bahan ke ruang pengering. Hal ini sejalan dengan penelitian Mrkic, dkk., (2006) yang mendapati bahwa dalam pengeringan brokoli hanya ada periode laju pengeringan menurun. Pada periode laju pengeringan menurun, air yang berdifusi dari dalam bahan merupakan air terikat. Air terikat memiliki energi pengikatan yang cukup kuat untuk dapat dilepaskan dari dalam bahan sehingga membutuhkan waktu pengeringan yang lama (Sutanto dan Pratiwi, 2007). 


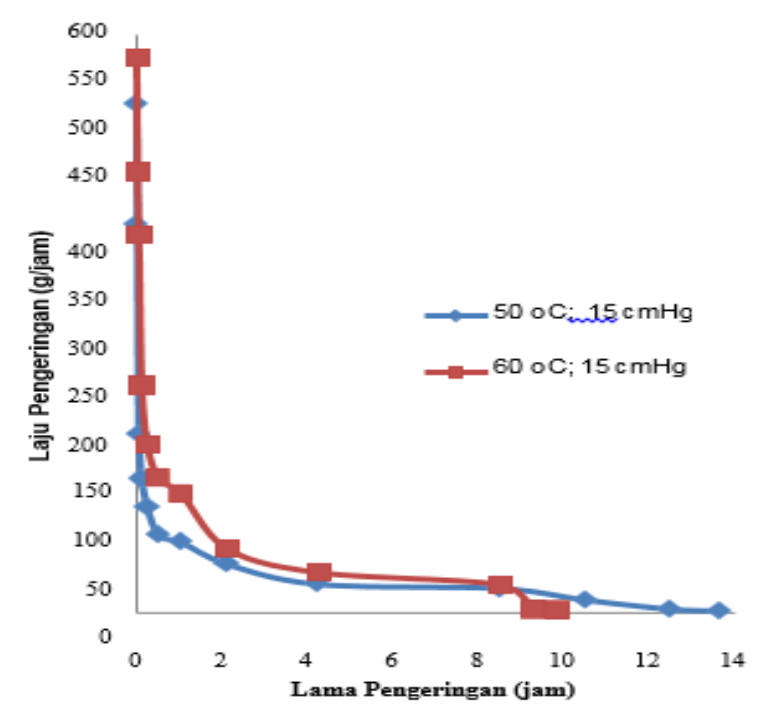

Gambar 2. Rata-rata Laju Pengeringan per Satuan Waktu

\section{K. Sifat-Sifat Termodinamika Udara Pengeringan Vakum}

Sifat-sifat termodinamika udara pada pengeringan vakum berbeda dengan pengeringan yang menggunakan tekanan atmosfer dapat dilihat pada Tabel 8. Hal ini disebabkan karena pada pengeringan vakum terjadi penurunan tekanan parsial uap air di dalam ruang pengering vakum dan perubahan sifatsifat termodinamika udara lainnya.

Tabel 8. Sifat-sifat Termodinamika Udara pada Grafik Psikometrik

\begin{tabular}{llc}
\hline Sifat Termodina-mika & $\begin{array}{c}\text { Tekanan vakum } \\
15 \mathrm{cmHg}\end{array}$ & Tekanan atmosfer \\
\hline Kelembaban mutlak $(\mathrm{kg}$ air/ kg udara kering) & 0,212 & 0,0446 \\
Kelembaban relatif $(\%)$ & 25,52 & 34,03 \\
Suhu bola basah $\left({ }^{\circ} \mathrm{C}\right)$ & 34 & 41,5 \\
Entalphi $(\mathrm{kJ} / \mathrm{kg})$ & 612,78 & 176,45 \\
Volume spesifik $\left(\mathrm{m}^{3} / \mathrm{kg}\right)$ & 6,411 & 1,011 \\
Suhu titik embun $\left({ }^{\circ} \mathrm{C}\right)$ & 33,2 & 38,4 \\
\hline
\end{tabular}

Menurunnya RH udara pengering menjadi $25,52 \%$ pada tekanan $15 \mathrm{cmHg}$ dengan suhu $50^{\circ} \mathrm{C}$ dan $60^{\circ} \mathrm{C}$ akan mempengaruhi sifat termodinamika udara lainnya seperti peningkatan nilai kelembaban mutlak, entalphi, dan volume spesifik pada ruang pengering vakum. Peningkatan ini terjadi karena adanya penghisapan udara di ruang pengering termasuk udara kering di ruang pengering vakum. Gambar 2. Rata-rata Laju Pengeringan per Satuan Waktu

Semakin tinggi nilai laju pengeringan maka jumlah air yang teruapkan selama proses pengeringan. Laju pengeringan menurun ditunjukkan pada bentuk grafik yang relatif menurun cukup curam dan landai karena laju pengeringannya semakin rendah. Selama periode udara kering yang terdapat pada ruang pengering vakum pun akan berkurang.

\section{KESIMPULAN}

Berdasarkan hasil penelitian yang telah dilakukan dan dianalisis maka kesimpulan bahwa perlakuan yang menghasilkan brokoli kering dengan kualitas terbaik adalah suhu pengeringan $60{ }^{\circ} \mathrm{C}$ dengan tekanan vakum $15 \mathrm{cmHg}$ dengan karakteristik fisik (rasio pengerutan 16,67\%, rasio rehidrasi $518,27 \%$, kadar air akhir 5,64 \% bk, bulk density $1056 \mathrm{~kg} / \mathrm{m}^{3}$ ), karakteristik kimia (protein 30,97\% dan vitamin C 189,24 mg/100 g), dan karakteristik optik (TCD 23,8). 


\section{DAFTAR PUSTAKA}

Afrianti, L. H. 2008. Teknologi Pengawetan Bahan Pangan. Bandung: Alfabeta. P: 9 dan 20.

Agustina, D. J. 2010. Model Pendugaan Laju Respirasi Brokoli (Brassica oleracea L. var. Italic) pada Berbagai Suhu Penyimpanan. Skripsi Institut Pertanian Bogor. P: 4.

Arthey, D., dan C. Dennis. 1991. Vegetables Processing. USA: VCH Publishers, Inc. P: 60.

Asgar, A dan D. Musaddad. 2006. Optimalisasi Cara, Suhu, dan Lama Blansing Sebelum Pengeringan Kubis. Journal of Horticultural. Vol. 16 (4):349-355.

Astuti, S. M. 2007. Teknik Mempertahankan Mutu Lobak (Rhaparus sativus) dengan Menggunakan Alat Pengering Vakum. Buletin Teknik Pertanian Vol. 12 (1): 30-34.

Astuti, S. M. 2008. Teknik Pengeringan Bawang Merah dengan Cara Perlakuan Suhu dan Tekanan Vakum. Buletin Teknik Pertanian Vol. 13 (2). P: 79-82.

Azeliya, R. M. 2013. Pembuatan Bolu Brokoli (Brassica oleracea L) Dilihat dari Kadar Beta Karoten dan Kadar Vitamin C serta Daya Terima. Naskah Publikasi Universitas Muhammadiyah Surakarta. P: 6, 8, dan 9.

Baochi, K., K.C. Bhan, dan H.C. Bhatnagar. 2009. Indian Standard Specification for Dehidrated Cabbage. New Delhi: Indian Standards Institution. P: 4.

Karnagi, C. 2001. Pengaruh Temperatur dan Tekanan pada Pembuatan Tepung Jamur Tiram Putih (Pleurotus ostreatus) Menggunakan Oven Vakum. Skripsi. Universitas Katolik Parahyangan. P: 4, 34,dan 39.

Kusumawati, D. D., B. S. Amanto, dan D. R. A. Muhammad. 2012. Pengaruh Perlakuan Pendahuluan dan Suhu Pengeringan Terhadap Sifat Fisik, Kimia, dan Sensori Tepung Biji Nangka (Artocarpus heterophyllus). Jurnal Teknosains Pangan Vol. 1 (1):41-48.

Listiorini, E., Syahraeni, dan Rostiati. 2014. Karakteristik Kimia dan Organoleptik Daging Buah Srikaya (Annona squamosa L.) pada Berbagai Suhu Pemanasan Pulp. e-i. Agrotekbis Vol. 2 (6): 596-603.

Mayor, L., dan A. M. Sereno. 2004. Modelling Shrinkage Daring Convective Drying of Food Materials. Journal of Food Engineering Vol. 61 (2004): 373-386.

Mrkic', V., M. Ukrainczyk, dan B. Tripalo. 2006. Applicability of Moisture Transfer Bi-Di Correlation for Convective Drying of Broccoli. Journal of Food Engineering Vol. 79 (2007). P: 640-646. Ophardt, C. E. 2003. Protein and Its Properties. New York: Marcel Dekker Inc. P: 34.

Purwitasari, A., Y. Hendrawan, dan R. Yulianingsih. 2014. Pengaruh Suhu dan Waktu Ekstraksi terhadap Sifat Fisik Kimia dalam Pembuatan Konsentrat Protein Kacang Komak (Lablab purpureus (L.) sweet). Jurnal Bioproses Komoditas Tropis.Vol. 2. (1). P: 42-53.

Saravacos, G. D. dan Z. B. Maroulis. 2011. Food Process Engineering Operations. New York: CRC Press Taylor \& Francis Group. P: 145, 366, 376, dan 382.

Sutanto, G. N. dan M. Pratiwi. 2007. Pengeringan Bahan Pangan. Undergraduate Theses of Institute Of Technology Bandung from JBPTITBPP / 2012-04-17. P: 8, 11, 12, dan 22-24.

Widyasanti, A. 2010. Determination Parameter and Mathematical Model Verification of Temperature Rise During Ohmic Pasteurization of Mixed Orange -Carrot Juice. Tesis Asian Institute of Technology. Bangkok.

Wijana, S., Sucipto, dan L. M. Sari. 2013. Pengaruh Suhu dan Waktu Pengeringan terhadap Aktivitas Antioksidan pada Bubuk Kulit Manggis (Garcinia mangostana L.). Skripsi Universitas Brawijaya. P: 40. 